\author{
칼슘의 수준별 급여 및 25-hydroxycholecalciferol의 사료 내 첨가가 종란 \\ 생산성 및 후기 난각질에 미치는 영향 \\ 김은집* · 안병기** · 강창원** \\ 천안연암대 동물보호계열*, 건국대학교 동물생명과학대학 동물자원연구센터**
}

\title{
Dietary Effects of Varying Levels of Calcium and 25-hydroxycholecalciferol on Hatching Egg Production and Eggshell Quality in Aged Egg-Type Breeder Hens
}

\author{
Eun Jib Kim*, Byoung Ki Ahn** and Chang Won Kang** \\ Division of Animal Care, Cheonan Yonam College*, \\ Animal Resources Research Center, College of Animal Bioscience and Technology, Konkuk University**
}

\begin{abstract}
This experiment was conducted to investigate the effects of dietary calcium $(\mathrm{Ca})$ and vitamin $\mathrm{D}_{3}$ metabolite on eggshell quality and hatching egg production in aged egg-type breeder hens. A total of five hundred and forty 60-week-old Hy-Line Brown breeder hens were randomly allocated to nine treatments in a $3 \times 3$ factorial design to determine the effects of dietary Ca levels (3.3, 3.9, and 4.5\%), combined with three levels of 25-hydroxycholecalciferol [25-(OH) $\mathrm{D}_{3} \quad 0$, 75, and $\left.150 \mu \mathrm{g} / \mathrm{kg}\right]$, on eggshell quality and egg production for 10 weeks. There were significant $\mathrm{Ca}$ and $25-(\mathrm{OH}) \mathrm{D}_{3}$ effects $(\mathrm{P}<0.01)$ on egg production rate. There was a linear $(\mathrm{P}<0.01)$ increase in eggshell strength and thickness with increasing dietary $\mathrm{Ca}$ and $25-(\mathrm{OH}) \mathrm{D}_{3}$ levels. Dietary $25-(\mathrm{OH}) \mathrm{D}_{3}$ had a significant effect $(\mathrm{P}<0.05)$ on hatchability of egg although fertility was not influenced by dietarylevels of Ca and 25- $(\mathrm{OH}) \mathrm{D}_{3}$. Dietary $\mathrm{Ca}$ levels affected $\mathrm{Ca}$ content in tibia $(\mathrm{P}<0.05)$. These results indicated that relatively high levels of dietary $\mathrm{Ca}$ in combination with $25-(\mathrm{OH}) \mathrm{D}_{3}$ had a beneficial effect on improving eggshell quality and reproductive performance in aged egg-type breeder hens.
\end{abstract}

(Key words : Ca, 25-hydroxycholecalciferol, Eggshell quality, Hatchability, Aged egg-type breeder hens)

\section{I. 서 론}

산란계 및 종계에서는 주령이 증가함에 따라 난각이 크 게 약화되는데 (Garlich 등, 1984), 주령의 증가에 의한 난 각질 저하는 장내에서의 $\mathrm{Ca}$ 흡수 감소와 더불어 난중이 증가하기 때문이다(Al-Batshan 등, 1994). 난각 형성에 가 장 큰 영향을 미치는 영양성분은 $\mathrm{Ca}$ 으로, 노계에서 난각 질 강화를 위한 영양적 연구에는 $\mathrm{Ca}$ 수준의 조절에 관련 된 연구가 다수 존재한다. 일반적으로 사료 내 $\mathrm{Ca}$ 을 적정 수준까지 증가시킬 때 난각질이 유의하게 개선되는 것으 로 알려져 있는데 (Mehring과 Titus, 1964; Walter와 Aitken, $1962)$, $\mathrm{Bar}$ 등 (2002)은 사료 내 $\mathrm{Ca}$ 수준을 $2.42 .5 \%$ 에서 $3.64 .0 \%$ 로 증가시켰을 때 난각중과 난각두께가 개선되었 고, $5.0 \%$ 수준까지 증가시켜도 생산성에 영향을 미치지 않으면서 난각중과 난각두께가 계속적으로 증가하는 결과
를 관찰하였다. 그러나 사료 내 $\mathrm{Ca}$ 수준이 너무 높으면 섭취량을 감소시킴으로서 난각질과 생산성에 부정적인 영 향을 미칠 수 있으며, 사료비의 상승 등 경제적인 문제 역시 고려되어야 한다(Hurwitz와 Bonstein, 1966; Ousterhout, 1980).

오래 전에 수행된 $\mathrm{Ca}$ 수준과 관련된 연구에서 $\mathrm{Harms}$ 와 Waldroup (1961) 및 Hurwitz와 Griminger(1962)는 적정 Ca 수준이 $2.75 \%$ 를 다소 상회하는 수준이라고 한데 반해, Keshavarz (2000) 및 Bar 등 (2002)에 의해 수행된 최근의 연구에서는 난각질 개선을 위해서는 $4.5 \%$ 내외의 상당히 높은 수준을 제시하고 있다. 이는 산란 능력의 향상에 따 라 $\mathrm{Ca}$ 요구량이 점차 높아졌음을 의미하는데, 산란계 사 료 내 적정 $\mathrm{Ca}$ 수준에 대해서는 실험에 이용된 공시계의 계통, 주령 및 $\mathrm{Ca}$ 공급원 및 입자도, 사양 환경 등과 같은 다양한 요인들을 고려한 실험설계가 필요할 것으로 생각

Corresponding author: Dr. C. W. Kang, College of Animal Bioscience and Technology, Konkuk University, 1 Hwayang-dong, Gwangjingu, Seoul 143-701, Korea. Tel: 82-2-450-3669, Fax: 82-2-452-9946, E-mail: kkucwkang@empal.com 
된다. 산란계에서 난각질 개선을 위한 목적으로 비타민 $\mathrm{D}_{3}$ 의 대사산물인 25-hydroxycholecalciferol [25-(OH)D $\mathrm{D}_{3}$ 이 다양하게 시험되었다(Marret 등, 1975; Soares 등, 1976). Charles 등 (1978)은 비타민 $\mathrm{D}_{3}$ 를 $200 \mathrm{IU}$ 로 낮게 설계한 산 란계 사료에 $25-(\mathrm{OH}) \mathrm{D}_{3}$ 를 첨가했을 때 난각질이 유의하게 개선되었다고 하였으나, 통상적인 $\mathrm{Ca}$ 및 $\mathrm{P}$ 수준을 유지한 사양조건에서 $25-(\mathrm{OH}) \mathrm{D}_{3}$ 에 의한 난각질 개선은 나타나지 않았으며 (Keshavarz, 2003), 강제환우시킨 계군에서도 25$(\mathrm{OH}) \mathrm{D}_{3}$ 의 대체가 난각질에 미치는 효과는 없었다는 상반 된 결과(Hamilton, 1980) 역시 보고되었다.

본 실험에서는 산란종계 노계에서 사료 내 $\mathrm{Ca}$ 수준 및 $25-(\mathrm{OH}) \mathrm{D}_{3}$ 의 첨가 수준을 다양하게 변화시켰을 때 종란 생산성 및 후기 난각질에 미치는 영향을 평가하였다.

\section{II. 재료 및 방법}

\section{1. 실험설계}

$\mathrm{Ca}$ 의 수준별 급여 및 25-(OH)D $\mathrm{D}_{3}$ [(주)로슈 비타민, Hy-D $\left.\mathrm{D}^{\circledR}\right]$ 의 사료 내 첨가가 종란 생산성 및 후기 난각질에 미치는 영향을 평가하기 위하여, 사료 내 $\mathrm{Ca}$ 의 수준을 $\mathrm{NRC}$ (1994) 요구량과 종계회사(Hy-Line Brown VARIETY, 2000) 및 Keshavarz(2000)의 권장 수준을 근거하여 사료 내 $3.3 \%, 3.9 \%$ 및 $4.5 \%$ 로 설정하였으며, $25-(\mathrm{OH}) \mathrm{D}_{3}$ 를 각 각 0,75 및 $150 \mu \mathrm{g} / \mathrm{kg}$ 수준으로 첨가하는 총 9개의 처리 (3×3 factorial design; 3 반복)를 구성하였다 (Table 1).

\section{2. 실험동물}

60주령 Hy-line Brown VARIETY 산란종계 암탉 540수와 수탉 54수를 실험동물로 공시하였다.

\section{3. 실험사료}

실험에 사용된 사료는 옥수수와 대두박을 기초로 하여 질소보정진정대사에너지(TMEn)는 $2,800 \mathrm{kcal} / \mathrm{kg}$ 으로, 조단 백질 함량은 $15 \%$ 로 동일하게 배합하였으며, 실험사료 내 다른 영양소 함량은 $\mathrm{NRC}$ (1994) 요구량에 명시된 양을 충 족시키거나 상회하는 수준으로 하였다. 실험사료 내 유효 인, 라이신 및 함유황아미노산 함량 역시 각각 $0.32 \%$, $0.80 \%$ 및 $0.64 \%$ 로 동일한 수준으로 하였다. 실험사료의 배합비 및 성분조성을 Table 2에 나타내었다.

\section{4. 사양관리}

공시계는 반복 당 각 22수씩 (암탉 20수+수탉 2수) 2단 철제 케이지 (너비 $180 \mathrm{~cm}$, 깊이 $90 \mathrm{~cm}$; 수당 $735 \mathrm{~cm}^{2}$ )에 서 사육하였다. 실험사료와 물은 자유채식 및 자유음수 시켰으며, 점등은 전 실험기간 동안 $16 \mathrm{~L}: 8 \mathrm{D}$ 로 고정하였 다. 기타 사양관리는 종계사양관리 방법 (Hy-Line Brown VARIETY, 2000)에 준하여 실시하였다.

\section{5. 조사항목}

\section{(1) 사료섭취량 및 난생산성}

사료섭취량은 급여량과 잔량을 1 주 간격으로 조사하여 각 반복별로 주당 섭취량을 산출하였다.

실험기간 동안 매일 오후 3 시에 수집한 산란 개수와 연 란, 파란 등을 합한 총 산란 개수를 사육수수로 나누어 산란율을 구하였으며, 수집된 계란전부의 무게를 측정하 여 계란 수로 나누어 평균 난중을 산출하였다.

(2) 난질 및 난각질

실험 사료 급여 후 주 단위로 생산된 계란을 반복구당

Table 1. Experimental design

\begin{tabular}{|c|c|c|c|}
\hline & \multicolumn{2}{|c|}{ Ca levels } & \multirow{2}{*}{$\begin{array}{c}25-(\mathrm{OH}) \mathrm{D}_{3} \text { levels }^{1} \\
(\mu \mathrm{g} / \mathrm{kg})\end{array}$} \\
\hline & $(\%)$ & Reference & \\
\hline T1 & 3.3 & \multirow{3}{*}{ NRC (1994) } & 0 \\
\hline $\mathrm{T} 2$ & 3.3 & & 75 \\
\hline $\mathbf{T 3}$ & 3.3 & & 150 \\
\hline $\mathrm{T} 4$ & 3.9 & Recommendation from Hy-Line & 0 \\
\hline T5 & 3.9 & \multirow{2}{*}{$\begin{array}{l}\text { Breeding company } \\
(2000)\end{array}$} & 75 \\
\hline T6 & 3.9 & & 150 \\
\hline $\mathbf{T 7}$ & 4.5 & \multirow{3}{*}{ Keshavarz (2000) } & 0 \\
\hline $\mathrm{T} 8$ & 4.5 & & 75 \\
\hline T9 & 4.5 & & 150 \\
\hline
\end{tabular}

\footnotetext{
1) 25-(OH) $\mathrm{D}_{3}, 25$-hydroxycholecalciferol.
} 
Table 2. Formula and chemical composition of experimental diets

\begin{tabular}{|c|c|c|c|}
\hline Items & $\mathrm{T} 1-\mathrm{T} 3$ & T4-T6 & $\mathrm{T} 7-\mathrm{T}^{1)}$ \\
\hline Yellow corn & 66.748 & 67.741 & 65.918 \\
\hline Soybean meal, Imported & 15.730 & 14.574 & 12.561 \\
\hline Corn gluten meal & 3.000 & 4.356 & 6.000 \\
\hline Animal fat & 1.700 & 1.700 & 2.194 \\
\hline Limestone & 7.800 & 9.386 & 11.018 \\
\hline Dicalcium phosphate & 1.291 & 1.373 & 1.392 \\
\hline Salt & 0.300 & 0.300 & 0.300 \\
\hline Lysine-HCl & 0.166 & 0.198 & 0.245 \\
\hline DL-Methionine & 0.090 & 0.079 & 0.068 \\
\hline Choline- $\mathrm{Cl}$ & 0.104 & 0.113 & 0.124 \\
\hline Mineral $\operatorname{mix}^{2)}$ & 0.100 & 0.100 & 0.100 \\
\hline Vitamin $\operatorname{mix}^{3}$ & 0.080 & 0.080 & 0.080 \\
\hline Wheat bran & 2.891 & - & - \\
\hline \multicolumn{4}{|l|}{ Calculated values } \\
\hline Crude protein, \% & 15.00 & 15.00 & 15.00 \\
\hline Ether extract, \% & 4.34 & 4.27 & 4.69 \\
\hline Crude fiber, $\%$ & 3.85 & 3.59 & 3.41 \\
\hline $\mathrm{Ca}, \%$ & 3.30 & 3.90 & 4.50 \\
\hline Available $\mathrm{P}, \%$ & 0.32 & 0.32 & 0.32 \\
\hline Lys, \% & 0.80 & 0.80 & 0.80 \\
\hline TSAA, $\%$ & 0.64 & 0.64 & 0.64 \\
\hline TMEn, $\mathrm{kcal} / \mathrm{kg}$ & 2,800 & 2,800 & 2,800 \\
\hline
\end{tabular}

1) $\mathrm{T} 1, \mathrm{Ca} 3.3 \%-25(\mathrm{OH}) \mathrm{D}_{3} 0 \mu \mathrm{g} ; \mathrm{T} 2$, Ca 3.3\%-25(OH)D $35 \mu \mathrm{g} ; \mathrm{T} 3$, Ca $3.3 \%-25(\mathrm{OH}) \mathrm{D}_{3} 150 \mu \mathrm{g} ; \mathrm{T} 4, \mathrm{Ca} 3.9 \%-25(\mathrm{OH}) \mathrm{D}_{3} 0$

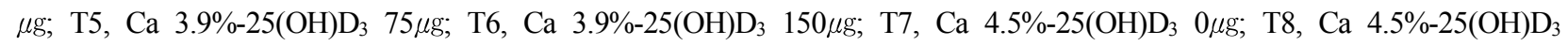
$75 \mu \mathrm{g} ; \mathrm{T} 9, \mathrm{Ca} 4.5 \%-25(\mathrm{OH}) \mathrm{D}_{3} 150 \mu \mathrm{g}$.

2) Mineral mixture provided following nutrients per $\mathrm{kg}$ of diet: $\mathrm{Fe}, 40 \mathrm{mg}$; $\mathrm{Zn}, 65 \mathrm{mg}$; Mn, $87 \mathrm{mg}$; $\mathrm{Cu}, 66 \mathrm{mg}$; I, $1.5 \mathrm{mg}$; Se, $0.1 \mathrm{mg}$.

3) Vitamin mixture provided following nutrients per $\mathrm{kg}$ of diet: vitamin $\mathrm{A}, 10,000 \mathrm{IU}$; vitamin $\mathrm{D}_{3}, 300 \mathrm{IU}$; vitamin $\mathrm{E}, 20$ IU; vitamin $\mathrm{K}_{3}, 2 \mathrm{mg}$; vitamin $\mathrm{B}_{1}, 2 \mathrm{mg}$; vitamin $\mathrm{B}_{2}, 5 \mathrm{mg}$; vitamin $\mathrm{B}_{6}, 3.5 \mathrm{mg}$; vitamin $\mathrm{B}_{12}, 0.02 \mathrm{mg}$; pantothenic acid, $12 \mathrm{mg}$; niacin, $30 \mathrm{mg}$; biotin, $0.12 \mathrm{mg}$; folic acid $0.7 \mathrm{mg}$.

10 개씩 수집하여 난각강도, 난각두께, Haugh unit 및 난황 색 등 난각질과 내부 난질 등의 관련 항목을 조사하였다. 난각강도는 난각 강도계 (FHK, Japan)를 이용하여 계란의 둔단부를 위로 하고 수직으로 고정한 후 압력을 가하여 파각되는 순간의 압력을 측정하였다. 난각 강도 측정 후 난백의 높이를 조사하여 난중을 대비한 Haugh unit 수치 를 구하였다 (FHK, Japan). 난각두께는 계란 중앙부의 난각 파편을 채취하여 난각 후도계(FHK Peacock, Japan)를 통 해 측정한 두께의 평균치로 하였다. 난황색은 Roche color fan과 대조한 색도로서 표시하였다.

(3) 종란율, 수정율 및 부화율

각 처리구별, 반복구별로 매일 산란된 계란에 대해서
선별 후 종란으로서의 사용 여부를 결정하였는데, 파란, 오염란, 기형란 및 $48 \mathrm{~g}$ 미만의 종란은 배제하였고 이를 종란율로 하였다. 얻어진 종란은 저장온도 $15 \sim 18^{\circ} \mathrm{C}$ 의 집 란실에서 150 개씩 수집될 때까지 저장한 후 입란하였다. 수정율을 부화 8 일령에 검란을 실시하여 유정란수를 부화 기 입란수로 나누어 산출하였으며, 부화율은 온도 $99.5^{\circ} \mathrm{F}$, 상대습도 $55 \sim 60 \%$ 의 조건을 갖춘 부화기(Petersime-576, Belgium)를 통해 부화된 초생추수를 부화기 입란수로 나 누어 산출하였다.

(4) 경골 내 회분 및 $\mathrm{Ca}$ 함량

실험종료 시에 반복구별로 체중이 유사한 개체를 2 수씩 선발하여 희생시킨 후 우측 경골을 적출하였다. 채취한 
경골 시료는 분석 전까지 뼈의 손상이 가장 적은 $-20^{\circ} \mathrm{C}$ 에서 보관하였으며(Seldin, 1965), 경골 시료를 잘게 세절 하고 $600^{\circ} \mathrm{C}$ 에서 24 시간 동안 회화시킨 후 무게를 측정하 여 회분함량을 조사하였다(Chang과 Coon, 1990).

\section{(5) 혈액 성분의 조성}

혈액 성분을 조사하기 위해 반복구별로 선발한 개체의 익하정맥에서 혈액을 채취하였으며, serum separating tube (VACCUTAINER SST, Becton Dickinson, Franklin Lake)에 넣어 원심분리 (2,500 rpm, 10 분) 후 혈청을 분리하여 분석 전까지 냉장 보관하였다. 준비된 혈청은 자동혈액분석기 (CX-7 Operator, Beckman Counter)를 사용하여 분석기에 설 치된 반응기 내에서 각각의 시약과 반응시킨 후 흡광도를 측정하였다. 혈청 내 albumin, glutamic-oxaloacetic transaminase (GOT), glutamic-pyruvic transaminase (GPT), blood urea nitrogen (BUN), $\mathrm{Ca}$ 및 $\mathrm{P}$ 농도를 조사하였다.

\section{6. 통계분석}

사양실험 및 분석을 통해 얻어진 자료들의 통계분석은 Statistical Analysis System(SAS, 2002)의 GLM program (two-way ANOVA procedure)을 이용하여 분산분석을 실시 하였고, 분산분석 상의 유의한 차이가 인정되는 경우
Duncan의 다중검정을 이용하여 처리간의 유의성을 검정하 였다 (Duncan, 1955). $\mathrm{Ca}$ 수준 및 25-(OH)D $\mathrm{D}_{3}$ 의 첨가 수준을 main effect로 하였고, $\mathrm{Ca} \times 25-(\mathrm{OH}) \mathrm{D}_{3}$ 의 interaction을 조사하 였다.

\section{III. 결과 및 고찰}

\section{1. 사료섭취량 및 난생산성에 미치는 영향}

$\mathrm{Ca}$ 급여 수준의 변화 및 $25-(\mathrm{OH}) \mathrm{D}_{3}$ 의 첨가 급여가 사료 섭취량, 산란율, 난중 및 종란율에 미치는 영향에 대한 결 과를 Table 3에 나타내었다. 사료섭취량은 $25-(\mathrm{OH}) \mathrm{D}_{3}$ 무첨 가구(T1, T4 및 $\mathrm{T} 7)$ 에서의 $\mathrm{Ca}$ 급여 수준의 변화에 따라 처리구간에 큰 차이는 없는 것으로 나타났다. 또한 25$(\mathrm{OH}) \mathrm{D}_{3}$ 급여 수준에 따른 사료섭취량의 차이는 통계적으 로 유의하지 않았다.

산란율은 $\mathrm{Ca}$ 급여 수준의 변화에 따라 처리구간에 유의 한 차이가 나타났으며 $(\mathrm{P}<0.01), 25-(\mathrm{OH}) \mathrm{D}_{3}$ 의 첨가에 의해 서도 유의한 변화 $(\mathrm{P}<0.01)$ 가 인정되었다. $\mathrm{Ca} 3.9 \%$ 급여구 (T4-T6)의 평균 산란율은 $66.83 \%$ 로 $\mathrm{Ca} 3.3 \%$ 급여구(T1-T3) 의 $65.90 \%$ 와 $\mathrm{Ca} 4.5 \%$ 급여구(T7-T9)의 $65.34 \%$ 에 비해 유 의하게 높았으며, $25-(\mathrm{OH}) \mathrm{D}_{3}$ 무첨가구 $(\mathrm{T} 1, \mathrm{~T} 4$ 및 $\mathrm{T} 7)$ 의 평 균 산란율 역시 $67.76 \%$ 로 $25-(\mathrm{OH}) \mathrm{D}_{3}$ 첨가구에 비해 유의

Table 3. Effects of dietary calcium and 25-hydroxycholecalciferol on laying performance and settable egg in aged egg-type breeder layers ${ }^{1,2}$

\begin{tabular}{ccccc}
\hline Treatments $^{3)}$ & Feed intake (g/hen/day) & Egg production (\%) & Egg weight $(\mathrm{g})$ & Settable egg (\%) \\
\hline \hline T1 & $113.1 \pm 1.24$ & $66.2 \pm 1.42$ & $64.4 \pm 0.27$ & $45.5 \pm 2.14$ \\
T2 & $107.9 \pm 2.34$ & $66.1 \pm 1.58$ & $64.2 \pm 1.14$ & $48.9 \pm 4.67$ \\
T3 & $112.7 \pm 2.34$ & $65.3 \pm 0.96$ & $64.6 \pm 0.10$ & $50.4 \pm 4.10$ \\
T4 & $116.7 \pm 1.47$ & $71.7 \pm 1.53$ & $64.7 \pm 0.33$ & $55.2 \pm 3.13$ \\
T5 & $104.5 \pm 3.12$ & $63.6 \pm 1.18$ & $63.6 \pm 0.26$ & $47.8 \pm 5.79$ \\
T6 & $113.3 \pm 2.68$ & $65.0 \pm 1.78$ & $64.3 \pm 0.36$ & $47.8 \pm 6.04$ \\
T7 & $115.5 \pm 1.67$ & $65.3 \pm 1.60$ & $65.0 \pm 0.31$ & $47.7 \pm 4.90$ \\
T8 & $114.0 \pm 2.09$ & $66.5 \pm 0.90$ & $64.4 \pm 0.43$ & $51.8 \pm 7.52$ \\
$\mathrm{~T} 9$ & $113.4 \pm 1.04$ & $64.2 \pm 1.44$ & $64.3 \pm 0.37$ & $51.7 \pm 3.50$ \\
\hline $\mathrm{Ca}$ & $\mathrm{NS}$ & $\mathrm{P}<0.01$ & $\mathrm{NS}$ & $\mathrm{NS}$ \\
$25-(\mathrm{OH}) \mathrm{D}_{3}$ & $\mathrm{NS}$ & $\mathrm{P}<0.01$ & $\mathrm{NS}$ & $\mathrm{NS}$ \\
$\mathrm{Ca} \times 25-(\mathrm{OH}) \mathrm{D}_{3}$ & $\mathrm{NS}$ & $\mathrm{P}<0.01$ & $\mathrm{NS}$ & $\mathrm{NS}$ \\
\hline
\end{tabular}

1) $25-(\mathrm{OH}) \mathrm{D}_{3}, 25$-hydroxycholecalciferol.

${ }^{2)} \mathrm{Mean} \pm \mathrm{SE}$

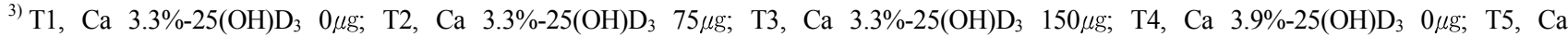
3.9\%-25(OH)D $33 \mu \mathrm{g} ; \mathrm{T} 6, \mathrm{Ca} 3.9 \%-25(\mathrm{OH}) \mathrm{D}_{3} \quad 150 \mu \mathrm{g} ; \quad \mathrm{T} 7, \mathrm{Ca} 4.5 \%-25(\mathrm{OH}) \mathrm{D}_{3} 0 \mu \mathrm{g} ; \mathrm{T} 8, \mathrm{Ca} 4.5 \%-25(\mathrm{OH}) \mathrm{D}_{3} \quad 75 \mu \mathrm{g} ; \mathrm{T} 9, \mathrm{Ca} \quad 4.5 \%-$ $25(\mathrm{OH}) \mathrm{D}_{3} 150 \mu \mathrm{g}$. 
하게 높은 것으로 나타났다. $\mathrm{Ca} \times 25-(\mathrm{OH}) \mathrm{D}_{3}$ 의 interaction에 서도 유의한 차이가 인정되었다 $(\mathrm{P}<0.01)$.

난중 및 종란율에서는 $\mathrm{Ca}$ 급여 수준의 변화와 25- $(\mathrm{OH}) \mathrm{D}_{3}$ 의 첨가에 따른 유의한 변화는 관찰되지 않았다. 사료 내 $\mathrm{Ca}$ 수준이 지나치게 낮거나 높으면 사료섭취량과 난생산 성이 저하되는 것으로 알려져 있다. Gilbert 등 (1981)은 사 료 내 $\mathrm{Ca}$ 수준이 $1 \%$ 이하일 때 사료섭취량이 감소한다고 하였고, Scott 등 (1971)은 $\mathrm{Ca}$ 가 5\% 이상이면 난생산성과 사료섭취량이 유의하게 감소한다고 하였다. $\mathrm{Ca}$ 수준이 $2.2 \%$ 이하 (Abdallah 등, 1993)일 때, 역으로 $6 \%$ 이상 (Jackson 등, 1987), 6.5\% 이상 (Keshavarz, 1986)인 조건에 서도 산란율의 저하가 나타났다. 그러나 Abdallah 등 (1993)은 $\mathrm{Ca}$ 수준을 $3.9 \%$ 에서 $4.4 \%$ 로 증가시켰을 때 사료 섭취량 및 산란율에 영향이 없었다고 하였고, Clunies 등 (1992) 역시 $\mathrm{Ca} 3.5 \%$ 급여구의 사료섭취량이 $2.5 \%$ 급여 시와 비교하여 유의하게 높았으나, $4.5 \%$ 급여구와는 차이 가 없었다고 하였다. 따라서 통상적인 급여 수준에서는 난생산성과 사료섭취량은 크게 영향을 받지 않는 듯 하다. 본 실험에서도 사료섭취량은 $\mathrm{Ca}$ 급여 $(3.3 \%, 3.9 \%$ 및 $4.5 \%$ ) 수준에 의한 영향이 없었으며, 상기의 선행연구 결 과와 일치하는 것으로 생각된다.

본 실험에서 $\mathrm{Ca}$ 급여 수준에 따라 사료섭취량은 변화가 없었으나 산란율이 유의하게 영향을 받은 것으로 나타났 다. $\mathrm{Ca} 3.9 \%$ 급여구의 평균 산란율이 $\mathrm{Ca} 3.3 \%$ 급여구 및 $\mathrm{Ca} 4.5 \%$ 급여구의 평균 산란율에 비해 유의하게 높았다. Damron과 Harms (1980)는 Ca 3.5\% 급여구의 산란율이 $2.5 \%$ 및 $6 \%$ 급여구에 비해 유의하게 높았다고 하였으며, 한 등 (1981)은 $\mathrm{Ca} 3.25 \%$ 급여구의 평균 산란율이 $3.25 \%$ 이하 급여구에 비해 유의하게 높았으나 $3.75 \%$ 급여구와는 차이가 없었다고 하였다. 본 연구에서는 $\mathrm{T} 4$ 처리구 $(\mathrm{Ca}$ $3.9 \%, 25-(\mathrm{OH}) \mathrm{D}_{3}$ 무첨가)의 산란율이 다른 처리구에 비해 현저히 높았기 때문에 이것에 의한 영향인지, 또는 실제 로 사료 내 $\mathrm{Ca}$ 수준이 산란율에 영향을 미친 것인지는 분 명치 않다.

한편 25- $(\mathrm{OH}) \mathrm{D}_{3}$ 첨가에 따른 영향은 무첨가구의 평균 산란율이 25- $(\mathrm{OH}) \mathrm{D}_{3}$ 첨가구에 비해 유의하게 높았으며, $25-(\mathrm{OH}) \mathrm{D}_{3}$ 의 사료 내 첨가가 산란율에 부정적인 영향을 미친 것으로 나타났다. 산란계 사료 내 $25-(\mathrm{OH}) \mathrm{D}_{3}$ 의 첨가 가 난 생산성에 미치는 영향에 대해서는 일치하지 않는 결과가 보고되었다. Marette 등 $(1975)$ 은 $25-(\mathrm{OH}) \mathrm{D}_{3}$ 의 급여 에 의해 산란율이 약 $10 \%$ 높아졌다고 하였으나, Charles와 Ernst (1973)는 비타민 $\mathrm{D} 3$ 와 $25-(\mathrm{OH}) \mathrm{D}_{3}$ 를 비교한 실험에서 $25-(\mathrm{OH}) \mathrm{D}_{3}$ 급여구의 산란율이 더 낮았다는 결과를 관찰하 였다. 난생산성의 결과가 다르게 나타난 것은 $25-(\mathrm{OH}) \mathrm{D}_{3}$ 의 사료 내 첨가 수준, 실험사료 내 비타민 $\mathrm{D}_{3}$ 수준 및 $\mathrm{P}$ 수준 등이 상이했기 때문으로 사료된다.
본 실험에서는 $\mathrm{Ca}$ 급여 수준에서는 난중 및 종란율은 변화가 없었다. 25- $(\mathrm{OH}) \mathrm{D}_{3}$ 의 첨가수준에 따른 난중에는 유의한 변화는 관찰되지 않았으며 종란율에는 통계적인 유의차는 없었으나 증가하는 경향이 나타났다. 사료 내 $\mathrm{Ca}$ 를 통상적인 급여 수준의 범위로 설정했을 때 난중에는 큰 영향을 미치지 않았으며, $25-(\mathrm{OH}) \mathrm{D}_{3}$ 의 급여 후에 난중 이 변화되었다는 연구 보고도 발견할 수 없었다.

\section{2. 난각강도, 난각두께, Haugh unit 및 난황색에 미치 는 영향}

$\mathrm{Ca}$ 급여 수준의 변화 및 $25-(\mathrm{OH}) \mathrm{D}_{3}$ 의 첨가 급여가 난각 강도 난각두께, Haugh unit 및 난황색에 미치는 영향을 Table 4에 나타내었다. 난각강도는 $\mathrm{Ca}$ 급여 수준의 변화 및 $25-(\mathrm{OH}) \mathrm{D}_{3}$ 의 첨가에 따른 유의한 변화 $(\mathrm{P}<0.01)$ 가 인정 되었다. 난각 강도는 $\mathrm{Ca} 4.5 \%$ 급여구(T7-T9)의 평균치가 $3.62 \mathrm{~kg} / \mathrm{cm}^{2}$ 로서 $\mathrm{Ca} 3.9 \%$ 급여구(T4-T6)의 $3.54 \mathrm{~kg} / \mathrm{cm}^{2}$ 와 $\mathrm{Ca} 3.3 \%$ 급여구(T1-T3)의 $3.44 \mathrm{~kg} / \mathrm{cm}^{2}$ 에 비해 유의하게 개 선되었다. $25-(\mathrm{OH}) \mathrm{D}_{3} 150 \mu \mathrm{g} / \mathrm{kg}$ 첨가구(T3, T6 및 $\left.\mathrm{T} 9\right)$ 의 평 균 난각 강도는 $3.66 \mathrm{~kg} / \mathrm{cm}^{2}$ 로 $25-(\mathrm{OH}) D_{3} 75 \mu \mathrm{g} / \mathrm{kg}$ 첨가구 $(\mathrm{T} 2, \mathrm{~T} 5$ 및 $\mathrm{T} 8)$ 의 $3.54 \mathrm{~kg} / \mathrm{cm}^{2}$ 및 $25-(\mathrm{OH}) \mathrm{D}_{3}$ 무첨가구(T1, $\mathrm{T} 4$ 및 $\mathrm{T} 7)$ 의 $3.40 \mathrm{~kg} / \mathrm{cm}^{2}$ 와 비교하여 유의하게 높았다.

난각두께 역시 $\mathrm{Ca}$ 급여 수준의 변화 및 $25-(\mathrm{OH}) \mathrm{D}_{3}$ 의 급 여에 의해 유의한 변화 $(\mathrm{P}<0.01)$ 가 인정되었다. $\mathrm{Ca} 4.5 \%$ 급 여구(T7-T9) 및 $\mathrm{Ca} 3.9 \%$ 급여구(T4-T6)에서 난각두께의 평 균치는 $37.77 \mathrm{~mm} \times 10^{-2}$ 및 $37.58 \mathrm{~mm} \times 10^{-2}$ 으로 $\mathrm{Ca} 3.3 \%$ 급여구(T1-T3)의 $37.10 \mathrm{~mm} \times 10^{-2}$ 에 비해 유의하게 높은 수 치가 관찰되었다. $25-(\mathrm{OH}) \mathrm{D}_{3} \quad 75 \mu \mathrm{g} / \mathrm{kg}$ 첨가구(T2, T5 및 $\mathrm{T} 8)$ 및 $25-(\mathrm{OH}) \mathrm{D}_{3} \quad 150 \mu \mathrm{g} / \mathrm{kg}$ 첨가구 $(\mathrm{T} 3, \mathrm{~T} 6$ 및 $\mathrm{T} 9)$ 의 평균 난각두께는 $37.85 \mathrm{~mm} \times 10^{-2}$ 및 $37.62 \mathrm{~mm} \times 10^{-2}$ 으로, $25-(\mathrm{OH}) \mathrm{D}_{3}$ 무첨가구 $(\mathrm{T} 1, \mathrm{~T} 4$ 및 $\mathrm{T} 7)$ 의 $36.98 \mathrm{~mm} \times 10^{-2}$ 에 비 해 유의하게 높았다. 난각강도 및 난각두께 모두 $\mathrm{Ca} \times 25$ $(\mathrm{OH}) \mathrm{D}_{3}$ 의 interaction에서도 유의한 변화 $(\mathrm{P}<0.01)$ 가 관찰되 었다. Haugh unit 및 난황색 항목에서는 $\mathrm{Ca}$ 급여 수준의 변화 및 25- $(\mathrm{OH}) \mathrm{D}_{3}$ 의 첨가에 따라 처리구간에 큰 차이는 없는 것으로 나타났다.

본 연구결과 $\mathrm{Ca}$ 급여 수준이 증가함에 따라 난각강도 및 난각두께에서 유의한 변화가 관찰되었다 $(\mathrm{P}<0.01)$. 일반 적으로 사료 내 $\mathrm{Ca}$ 이 부족하면 난각이 얇아지는 문제가 발생하며 (Bar 등, 2002), 사료 내 $\mathrm{Ca}$ 을 적정 수준까지 증 가시키면 난각의 calcification이 향상되고 (Hartel, 1989), 난 각질이 유의하게 개선되는 것으로 알려져 있다 (Mehring과 Titus, 1964; Walter와 Aitken, 1962). 역으로 사료 내 $\mathrm{Ca}$ 수 준이 너무 높으면 섭취량을 감소시킴으로서 난각질에 부 정적인 영향을 미칠 수 있다는 보고도 있었다 (Hurwitz와 Bonstein, 1966; Ousterhout, 1980). Jackson 등 (1987)은 Ca 
Kim et al. ; Calcium, 25-Hydroxycholecalciferol and Eggshell Quality

Table 4. Effects of dietary calcium and 25-hydroxycholecalciferol on egg and eggshell qualities in aged egg-type breeder layers ${ }^{1,2)}$

\begin{tabular}{ccccc}
\hline Treatments $^{3)}$ & Shell strength $\left(\mathrm{kg} / \mathrm{cm}^{2}\right)$ & Shell thickness $\left(\mathrm{mm} \times 10^{-2}\right)$ & Haugh unit & Yolk color \\
\hline T1 & $3.33 \pm 0.12$ & $36.63 \pm 0.14$ & $85.05 \pm 1.47$ & $7.98 \pm 0.14$ \\
$\mathrm{~T} 2$ & $3.48 \pm 0.06$ & $37.88 \pm 0.31$ & $84.90 \pm 1.47$ & $8.03 \pm 0.18$ \\
$\mathrm{~T} 3$ & $3.53 \pm 0.11$ & $36.80 \pm 0.18$ & $83.98 \pm 2.04$ & $8.05 \pm 0.10$ \\
$\mathrm{~T} 4$ & $3.40 \pm 0.10$ & $36.80 \pm 0.04$ & $84.35 \pm 2.32$ & $8.10 \pm 0.20$ \\
$\mathrm{~T} 5$ & $3.60 \pm 0.09$ & $37.95 \pm 0.46$ & $85.13 \pm 1.35$ & $8.08 \pm 0.13$ \\
$\mathrm{~T} 6$ & $3.63 \pm 0.05$ & $37.98 \pm 0.17$ & $85.20 \pm 1.25$ & $8.13 \pm 0.14$ \\
$\mathrm{~T} 7$ & $3.48 \pm 0.03$ & $37.50 \pm 0.23$ & $81.83 \pm 1.86$ & $8.13 \pm 0.16$ \\
$\mathrm{~T} 8$ & $3.55 \pm 0.06$ & $37.73 \pm 0.14$ & $81.30 \pm 1.25$ & $8.13 \pm 0.19$ \\
$\mathrm{~T} 9$ & $3.83 \pm 0.09$ & $38.08 \pm 0.34$ & $84.25 \pm 1.75$ & $8.15 \pm 0.15$ \\
$\mathrm{Ca}$ & $\mathrm{P}<0.01$ & $\mathrm{P}<0.01$ & $\mathrm{NS}$ & $\mathrm{NS}$ \\
$\mathrm{Ca} \times 25-(\mathrm{OH}) \mathrm{D}_{3}$ & $\mathrm{P}<0.01$ & $\mathrm{P}<0.01$ & $\mathrm{NS}$ & $\mathrm{NS}$ \\
\hline
\end{tabular}

1) 25-(OH) $\mathrm{D}_{3}$, 25-hydroxycholecalciferol.

${ }^{2)} \mathrm{Mean} \pm \mathrm{SE}$

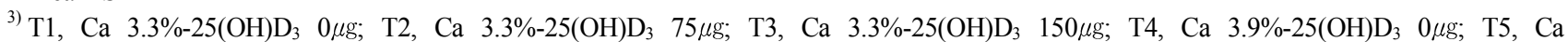
$3.9 \%-25(\mathrm{OH}) \mathrm{D}_{3} \quad 75 \mu \mathrm{g} ; \mathrm{T} 6$, Ca $3.9 \%-25(\mathrm{OH}) \mathrm{D}_{3} \quad 150 \mu \mathrm{g} ; \mathrm{T} 7, \mathrm{Ca} 4.5 \%-25(\mathrm{OH}) \mathrm{D}_{3} \quad 0 \mu \mathrm{g} ; \mathrm{T} 8, \mathrm{Ca} 4.5 \%-25(\mathrm{OH}) \mathrm{D}_{3} \quad 75 \mu \mathrm{g} ; \mathrm{T} 9$, Ca $4.5 \%-$ $25(\mathrm{OH}) \mathrm{D}_{3} \quad 150 \mu \mathrm{g}$

수준을 $3.0 \%$ 에서 $9.0 \%$ 까지 $1.5 \%$ 씩 증가시킨 실험사료를 급여했을 때 $6 \%$ 이상 급여 시 난생산성은 유의한 감소를 보였으나 전 산란기간의 평균 난각 파괴강도가 유의하게 증가하였다고 보고하였다. Clunies 등 (1992)도 42주령의 백색 산란계를 공시하여 $\mathrm{Ca}$ 수준을 $2.5 \%$ 에서 $4.5 \%$ 까지 달리한 실험사료를 급여한 연구에서 $\mathrm{Ca}$ 수준의 증가와 더 불어 난각중이 유의하게 증가하였으며, 난각이상의 비율 은 유의하게 감소하는 결과를 관찰하였다. Bar 등(2002) 역시 다양한 계통의 산란계를 공시한 연구에서 사료 내 $\mathrm{Ca}$ 수준을 2.4 2.5\%에서 3.6 4.0\%로 증가시켰을 때 난각 중과 난각두께가 개선되었고, $5.0 \%$ 수준까지 증가시켜도 생산성에 영향을 미치지 않으면서 난각중과 난각두께가 계속적으로 증가하는 결과를 관찰하였다. 한편 한 등 (1981)은 백색 산란계에 $1.75 \%$ 부터 $3.75 \%$ 까지 다양한 수 준으로 $\mathrm{Ca}$ 를 급여했을 때 $3.25 \%$ 수준까지는 난각두께가 개선되었으나 $3.25 \%$ 급여구와 $3.75 \%$ 급여구간에는 차이가 없었다고 하였다. Keshavarz(1986)는 56주령의 공시계에 $\mathrm{Ca}$ 수준이 $3.5,4.5$ 및 $5.5 \%$ 인 실험사료를 급여한 결과, 난 각질에 큰 변화가 없었다고 하였으며, 후속 연구를 통해 서도 1 일 $3.75 \mathrm{~g}$ 이상의 $\mathrm{Ca}$ 을 섭취하여도 난각질의 개선효 과는 기대하기 어려우며, $\mathrm{NRC} \mathrm{(1984)의} \mathrm{Ca}$ 요구량으로 충
분하다고 하였다 (Keshavarz와 Nakajima, 1991).

또한 본 실험에서 $25-(\mathrm{OH}) \mathrm{D}_{3}$ 의 첨가 급여에 의해서 난 각질이 유의하게 개선되는 결과가 얻어졌다 $(\mathrm{P}<0.01)$. Hamilton (1980)은 25-(OH)D 가 산란율과 난각중을 유의하 게 개선시키지 못했다고 보고한 반면, 다른 선행연구들은 $25-(\mathrm{OH}) \mathrm{D}_{3}$ 의 첨가 급여에 의한 난각질 개선 효과가 비타 민 $\mathrm{D}_{3}$ 와 동일하거나 긍정적인 효과가 있다고 일치하는 결 과를 제시하였다(McLoughlin과 Soarse, 1976). Charles와 Ernst (1973)는 74주령의 노계에 $25-(\mathrm{OH}) \mathrm{D}_{3}$ 를 급여했을 때 난각강도 개선 효과가 인정되었다고 하였고, Polin과 Ringer (1977) 역시 난각강도를 증가시켰다는 유사한 결과 를 관찰하였다. Marret 등 (1975) 역시 장기간 25-(OH)D 를 급여하면 더 두꺼운 난각두께의 계란을 얻을 수 있다고 하였다. 사료 내 $\mathrm{P}$ 수준을 제한하지 않은 연구에서는 $25-(\mathrm{OH}) \mathrm{D}_{3}$ 의 효과를 얻기 어렵다는 지적이 있으며(Soares 등, 1995), Angel 등(2001), Applegate 등(2000)의 연구를 통 해서도 $25-(\mathrm{OH}) \mathrm{D}_{3}$ 에 의한 $\mathrm{P}$ 절약효과가 입증된 바 있다. 본 연구에서 실험사료 내의 유효인이 $0.32 \%$ 로 $\mathrm{NRC}$ (1994) 요구량보다 상회하는 수준으로 난각질 개선 효과는 인 절약효과라기 보다는 $25-(\mathrm{OH}) \mathrm{D}_{3}$ 첨가 효과로 보는 것 이 타당할 것이다. 


\section{3. 수정율 및 부화율에 미치는 영향}

$\mathrm{Ca}$ 급여 수준의 변화 및 $25-(\mathrm{OH}) \mathrm{D}_{3}$ 의 첨가 급여가 수정 율과 부화율에 미치는 영향을 Table 5에 나타내었다. 수정 율은 $\mathrm{Ca}$ 급여수준 변화와 $25-(\mathrm{OH}) \mathrm{D}_{3}$ 의 첨가 급여에 따라 처리구간에 큰 차이는 없는 것으로 나타났다. $\mathrm{T} 8$ 처리구 의 수정율이 $82.46 \%$ 로 가장 낮았고 $\mathrm{T} 3$ 처리구에서 $89.86 \%$ 로 가장 높았으나, 처리간에 유의한 변화는 인정되 지 않았다. 입란대 부화율은 $\mathrm{Ca}$ 급여 수준의 변화에 따라 처리구간에 큰 차이가 없었으나, $25-(\mathrm{OH}) \mathrm{D}_{3}$ 의 첨가에 의 해 유의한 변화 $(\mathrm{P}<0.05)$ 가 나타났다. 25- $(\mathrm{OH}) \mathrm{D}_{3} \quad 150 \mu \mathrm{g} / \mathrm{kg}$ 첨가구(T3, T6 및 $\mathrm{T} 9)$ 의 입란대 부화율 평균은 $74.19 \%$ 로 $25-(\mathrm{OH}) \mathrm{D}_{3}$ 무첨가구 $(\mathrm{T} 1, \mathrm{~T} 4$ 및 $\mathrm{T} 7)$ 의 $66.64 \%$ 에 비해 유의 하게 높은 수치를 나타내었다. $25-(\mathrm{OH}) \mathrm{D}_{3} 75 \mu \mathrm{g} / \mathrm{kg}$ 첨가구 (T2, T5 및 T8)의 입란대 부화율 평균은 $68.99 \%$ 로 25 $(\mathrm{OH}) \mathrm{D}_{3}$ 무첨가구에 비해서는 다소 높았으나 유의한 차이 는 인정되지 않았다. $\mathrm{Ca} \times 25-(\mathrm{OH}) \mathrm{D}_{3}$ 의 interaction에서 유의 한 변화는 관찰되지 않았다.

Abdulrahim 등 (1979)은 부화율 개선에 있어서는 1,25 $(\mathrm{OH}) 2 \mathrm{D}_{3}$ 가 비타민 $\mathrm{D}_{3}$ 의 역할을 하지 못하는데 반해, $25-(\mathrm{OH}) \mathrm{D}_{3}$ 가 부화율에 미치는 효과가 비타민 $\mathrm{D}_{3}$ 와 유사하 다고 하였다. Manley 등(1978)은 비타민 $\mathrm{D}_{3}$ 가 결핍된 사료 에 비타민 $\mathrm{D}_{3}(2,200 \mathrm{IU} / \mathrm{kg})$ 와 $25-(\mathrm{OH}) \mathrm{D}_{3}(1,100 \mathrm{IU} / \mathrm{kg})$ 를 첨가
급여했을 때 칠면조에서 $25-(\mathrm{OH}) \mathrm{D}_{3}$ 에 의한 부화율 개선 효과가 더 컸다고 보고하였다. $25-(\mathrm{OH}) \mathrm{D}_{3}$ 의 첨가 급여에 의한 부화율의 개선 효과는 비타민 $\mathrm{D}_{3}$ 및 $1,25(\mathrm{OH})_{2} \mathrm{D}_{3}$ 에 비해 vitalline 막을 더 효율적으로 통과하기 때문이라는 주장이 있다(Ameenuddin, 1984). 종계사료 내 비타민 $\mathrm{D}_{3}$ 수준을 유지하면서 $25-(\mathrm{OH}) \mathrm{D}_{3}$ 를 $150 \mu \mathrm{g} / \mathrm{kg}$ 수준으로 추가 공급함으로서 부화율의 개선 효과를 기대할 수 있을 것으 로 사료된다.

\section{4. 경골 내 조회분, $\mathrm{Ca}$ 및 $\mathrm{P}$ 함량에 미치는 영향}

$\mathrm{Ca}$ 급여 수준의 변화 및 $25-(\mathrm{OH}) \mathrm{D}_{3}$ 의 첨가 급여가 경골 내 조회분, $\mathrm{Ca}$ 및 $\mathrm{P}$ 함량에 미치는 영향에 대한 결과는 Table 6에 제시하였다. 경골 내 조회분 함량에서는 $\mathrm{Ca}$ 급 여 수준의 변화 및 25- $(\mathrm{OH}) \mathrm{D}_{3}$ 의 첨가에 따른 처리구간에 유의한 차이는 관찰되지 않았다. 경골 내 $\mathrm{Ca}$ 함량은 $\mathrm{Ca}$ 급여 수준의 변화에 따라 처리구간에 유의한 차이가 나타 났으나 $(\mathrm{P}<0.05), 25-(\mathrm{OH}) \mathrm{D}_{3}$ 의 첨가 효과는 인정되지 않았 다. $\mathrm{Ca} 4.5 \%$ 급여구 (T7-T9)의 경골 내 평균 $\mathrm{Ca}$ 함량은 $18.12 \%$ 로 $\mathrm{Ca} 3.3 \%$ 급여구(T1-T3)의 $14.29 \%$ 및 $\mathrm{Ca} 3.9 \%$ 급여구(T4-T6)의 $14.71 \%$ 에 비해 유의하게 높은 수치를 나 타내었다. $\mathrm{Ca} \times 25-(\mathrm{OH}) \mathrm{D}_{3}$ 의 interaction에서 유의한 변화는 관찰되지 않았다. 경골 내 $\mathrm{P}$ 함량에서는 $\mathrm{Ca}$ 급여 수준의

Table 5. Effects of dietary calcium and 25-hydroxycholecalciferol on fertility and hatchability in aged egg-type breeder layers ${ }^{1,2)}$

\begin{tabular}{|c|c|c|c|c|c|}
\hline \multirow{2}{*}{ Treatments ${ }^{3)}$} & \multirow{2}{*}{ Fertility (\%) } & \multicolumn{2}{|c|}{ Hatch of fertile egg (\%) } & \multicolumn{2}{|c|}{ Hatch of egg set $(\%)$} \\
\hline & & Female & Total & Female & Total \\
\hline $\mathrm{T} 1$ & $87.2 \pm 1.45$ & $38.6 \pm 1.62$ & $77.4 \pm 3.64$ & $33.6 \pm 1.11$ & $67.5 \pm 3.45$ \\
\hline $\mathrm{T} 2$ & $87.3 \pm 4.04$ & $41.8 \pm 0.95$ & $84.6 \pm 1.82$ & $36.4 \pm 1.21$ & $73.8 \pm 3.17$ \\
\hline $\mathrm{T} 3$ & $89.8 \pm 1.53$ & $42.1 \pm 2.44$ & $86.4 \pm 3.90$ & $37.8 \pm 1.59$ & $77.6 \pm 3.40$ \\
\hline $\mathrm{T} 4$ & $86.8 \pm 1.76$ & $35.4 \pm 3.79$ & $77.7 \pm 7.60$ & $30.8 \pm 2.34$ & $67.6 \pm 7.52$ \\
\hline $\mathrm{T} 5$ & $88.6 \pm 2.10$ & $37.9 \pm 2.73$ & $75.8 \pm 4.42$ & $33.5 \pm 1.55$ & $67.1 \pm 2.89$ \\
\hline T6 & $89.3 \pm 1.41$ & $41.8 \pm 2.82$ & $82.5 \pm 1.50$ & $37.3 \pm 3.49$ & $73.6 \pm 1.14$ \\
\hline $\mathrm{T} 7$ & $83.4 \pm 5.77$ & $37.9 \pm 1.95$ & $77.7 \pm 1.12$ & $31.7 \pm 3.22$ & $64.7 \pm 3.71$ \\
\hline $\mathrm{T} 8$ & $82.4 \pm 3.05$ & $38.6 \pm 1.92$ & $80.2 \pm 2.00$ & $31.7 \pm 0.86$ & $66.0 \pm 0.84$ \\
\hline $\mathrm{T} 9$ & $83.2 \pm 1.88$ & $38.7 \pm 1.44$ & $85.6 \pm 3.45$ & $32 . .3 \pm 1.85$ & $71.3 \pm 3.49$ \\
\hline $\mathrm{Ca}$ & NS & NS & NS & NS & NS \\
\hline $25-(\mathrm{OH}) \mathrm{D}_{3}$ & NS & NS & NS & NS & $\mathrm{P}<0.05$ \\
\hline $\mathrm{Ca} \times 25-(\mathrm{OH}) \mathrm{D}_{3}$ & NS & NS & NS & NS & NS \\
\hline
\end{tabular}

1) 25-(OH) $\mathrm{D}_{3}, 25$-hydroxycholecalciferol.

${ }^{2)}$ Mean $\pm \mathrm{SE}$

3) $\mathrm{T} 1, \mathrm{Ca} 3.3 \%-25(\mathrm{OH}) \mathrm{D}_{3} 0 \mu \mathrm{g} ; \mathrm{T} 2, \mathrm{Ca} 3.3 \%-25(\mathrm{OH}) \mathrm{D}_{3} \quad 75 \mu \mathrm{g} ; \mathrm{T} 3, \mathrm{Ca} 3.3 \%-25(\mathrm{OH}) \mathrm{D}_{3} \quad 150 \mu \mathrm{g} ; \mathrm{T} 4, \mathrm{Ca} 3.9 \%-25(\mathrm{OH}) \mathrm{D}_{3} \quad 0 \mu \mathrm{g} ; \mathrm{T} 5, \mathrm{Ca}$ $3.9 \%-25(\mathrm{OH}) \mathrm{D}_{3} \quad 75 \mu \mathrm{g} ; \mathrm{T} 6, \mathrm{Ca} 3.9 \%-25(\mathrm{OH}) \mathrm{D}_{3} \quad 150 \mu \mathrm{g} ; \mathrm{T} 7, \mathrm{Ca} \quad 4.5 \%-25(\mathrm{OH}) \mathrm{D}_{3} 0 \mu \mathrm{g} ; \mathrm{T} 8, \mathrm{Ca} 4.5 \%-25(\mathrm{OH}) \mathrm{D}_{3} \quad 75 \mu \mathrm{g} ; \mathrm{T} 9, \mathrm{Ca} \quad 4.5 \%-$ $25(\mathrm{OH}) \mathrm{D}_{3} 150 \mu \mathrm{g}$. 
Kim et al. ; Calcium, 25-Hydroxycholecalciferol and Eggshell Quality

Table 6. Effects of dietary calcium and 25-hydroxycholecalciferol on proximate composition of tibia in aged egg-type breeder layers ${ }^{1,2}$

\begin{tabular}{|c|c|c|c|}
\hline Treatments $^{3)}$ & Crude ash $(\%)$ & $\mathrm{Ca}(\%)$ & $\mathrm{P}(\%)$ \\
\hline $\mathrm{T} 1$ & $33.57 \pm 0.86$ & $11.81 \pm 1.93$ & $1.34 \pm 0.26$ \\
\hline $\mathrm{T} 2$ & $36.39 \pm 1.73$ & $17.33 \pm 3.76$ & $1.68 \pm 0.09$ \\
\hline $\mathrm{T} 3$ & $32.42 \pm 0.76$ & $13.72 \pm 1.62$ & $1.80 \pm 0.02$ \\
\hline $\mathrm{T} 4$ & $35.64 \pm 2.16$ & $12.97 \pm 1.60$ & $1.72 \pm 0.02$ \\
\hline $\mathrm{T} 5$ & $37.52 \pm 2.81$ & $16.18 \pm 1.79$ & $1.81 \pm 0.06$ \\
\hline T6 & $34.80 \pm 1.49$ & $14.99 \pm 1.01$ & $1.72 \pm 0.02$ \\
\hline $\mathrm{T} 7$ & $35.26 \pm 1.85$ & $17.97 \pm 1.09$ & $1.72 \pm 0.02$ \\
\hline $\mathrm{T} 8$ & $34.77 \pm 0.95$ & $16.70 \pm 2.05$ & $1.64 \pm 0.11$ \\
\hline $\mathrm{T} 9$ & $37.79 \pm 2.55$ & $19.71 \pm 0.53$ & $1.45 \pm 0.12$ \\
\hline $\mathrm{Ca}$ & NS & $\mathrm{P}<0.05$ & NS \\
\hline $25-(\mathrm{OH}) \mathrm{D}_{3}$ & NS & NS & NS \\
\hline $\mathrm{Ca} \times 25-(\mathrm{OH}) \mathrm{D}_{3}$ & NS & NS & $\mathrm{P}<0.05$ \\
\hline
\end{tabular}

1) 25-(OH) $\mathrm{D}_{3}, 25$-hydroxycholecalciferol.

${ }^{2)} \mathrm{Mean} \pm \mathrm{SE}$

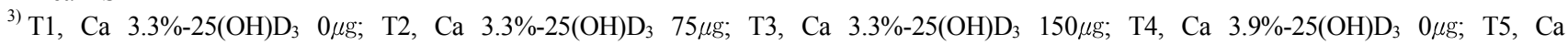
$3.9 \%-25(\mathrm{OH}) \mathrm{D}_{3} 75 \mu \mathrm{g} ; \mathrm{T} 6$, Ca $3.9 \%-25(\mathrm{OH}) \mathrm{D}_{3} 150 \mu \mathrm{g} ; \quad \mathrm{T} 7, \mathrm{Ca} 4.5 \%-25(\mathrm{OH}) \mathrm{D}_{3} \quad 0 \mu \mathrm{g} ; \mathrm{T} 8, \mathrm{Ca} 4.5 \%-25(\mathrm{OH}) \mathrm{D}_{3} \quad 75 \mu \mathrm{g} ; \mathrm{T} 9, \mathrm{Ca} \quad 4.5 \%-$ $25(\mathrm{OH}) \mathrm{D}_{3} 150 \mu \mathrm{g}$.

변화 및 25- $(\mathrm{OH}) \mathrm{D}_{3}$ 의 첨가에 따른 처리구간에 유의한 차 이는 없었으나, $\mathrm{Ca} \times 25-(\mathrm{OH}) \mathrm{D}_{3}$ 의 interaction에서는 유의한 변화가 관찰되었다 $(\mathrm{P}<0.05)$.

Abdallah 등(1993)은 $\mathrm{Ca}$ 수준이 $3.9 \%$ 와 $4.4 \%$ 인 실험사료 를 비교했을 때 파쇄강도 및 경골 내 조회분 함량에서 차 이가 없었다고 하였고, Keshavarz (1986) 역시 56주령의 공 시계에 $\mathrm{Ca}$ 이 $3.5,4.5$ 및 $5.5 \%$ 함유된 실험사료를 급여한 연구에서 경골 내 조회분 함량의 차이를 발견하지 못하였 다. Garlich 등 (1984)은 경골 내 조회분 함량이 골격의 상 태를 예측할 수 있는 지표가 된다고 하였는데, 본 실험에 서는 $\mathrm{Ca}$ 급여 수준의 변화 및 $25-(\mathrm{OH}) \mathrm{D}_{3}$ 의 첨가에 따른 처리구간에 유의한 차이는 관찰되지 않았다. 한편, 본 연 구에서 $\mathrm{Ca} 3.3 \%$ 및 $3.9 \%$ 급여구간에는 경골 내 $\mathrm{Ca}$ 함량 에서 큰 차이가 없었으나, $\mathrm{Ca} 4.5 \%$ 급여구에서는 유의한 증가를 나타내었다. Mehring과 Titus (1964), Walter와 Aitken (1962)은 사료 내 $\mathrm{Ca}$ 수준이 증가할 때 경골 내 $\mathrm{Ca}$ 함량 이 증가하는 경향을 보이거나 유의하게 증가하였다는 본 연구와 일치하는 결과를 보고하였다. 대조적으로 한 등 (1981)은 200일령의 백색계를 공시하여 $\mathrm{Ca}$ 수준이 $1.75 \%$ 부터 $3.75 \%$ 까지 단계적으로 급여한 실험에서는 경골 내 $\mathrm{Ca}$ 함량이 $20 \%$ 내외로 유의적인 차이 없이 비교적 일정
하였다고 보고한 바 있다. 경골 내 $\mathrm{Ca}$ 및 $\mathrm{P}$ 함량은 $\mathrm{Ca}$ 공 급원 또는 급여 수준에 따라 영향을 받지 않는다는 결과 는 본 실험에서 나타난 경골 내 $\mathrm{Ca}$ 함량의 변화와는 상이 한 결과로서, 공시계의 주령, 실험사료 내 $\mathrm{Ca}$ 및 $\mathrm{P}$ 수준 그리고 $\mathrm{Ca}$ 대사에 영향을 미칠 수 있는 영양성분 등 실험 조건에 따라 다양한 결과가 나타날 수 있을 것이다.

25- $(\mathrm{OH}) \mathrm{D}_{3}$ 의 급여가 골격성상에 미치는 영향에 대한 선 행연구의 결과는 비타민 $\mathrm{D}_{3}$ 에 비해 상당히 효과적인 것으 로 알려져 있다. McNaughton 등(1977)은 골격 내 조회분 함량을 지표로 했을 때 $25-(\mathrm{OH}) \mathrm{D}_{3}$ 가 비타민 $\mathrm{D}_{3}$ 에 비해 1.5 배 효과가 있다고 하였으며, Soares 등(1978) 역시 P 결 핍 기초사료 급여 조건에서는 골격 내 조회분 함량을 증 가시키는데 2-2.5배 더 효과적이라고 하였다. 본 실험에서 는 경골 내 조회분 및 $\mathrm{Ca}$ 함량이 $25-(\mathrm{OH}) \mathrm{D}_{3}$ 의 첨가 급여 에 의한 영향을 받지 않음으로서 선행연구와 다른 결과가 얻어졌다. 선행연구에서는 비타민 $\mathrm{D}_{3}$ 가 부족하거나 결핍 된 기초사료에 또는 사료 내 $\mathrm{P}$ 수준이 부족한 기초사료에 $25-(\mathrm{OH}) \mathrm{D}_{3}$ 를 부가한 실험 조건이었기 때문에 유효인과 비 타민 $\mathrm{D}_{3}$ 가 충족된 조건에서 $25-(\mathrm{OH}) \mathrm{D}_{3}$ 를 부가했던 본 연 구와는 다른 결과가 얻어진 것으로 생각된다. 박 (2003)의 $25-(\mathrm{OH}) \mathrm{D}_{3}$ 관련 연구에서도 $\mathrm{P}$ 결핍사료에 25- $(\mathrm{OH}) \mathrm{D}_{3}$ 를 
$75 \mu \mathrm{g} / \mathrm{kg}$ 수준으로 첨가 급여했을 때 육계에서 경골의 파 쇄강도 및 조회분 함량이 유의하게 증가하였다.

\section{5. 혈액 성상에 미치는 영향}

$\mathrm{Ca}$ 급여 수준의 변화 및 $25-(\mathrm{OH}) \mathrm{D}_{3}$ 의 첨가 급여가 혈액 성상에 미치는 영향을 Table 7에 나타내었다. 혈청 내 albumin 및 GOT 수치는 처리구간에 큰 차이가 없었으며, $\mathrm{Ca}$ 급여 수준, $25-(\mathrm{OH}) \mathrm{D}_{3}$ 의 첨가 급여 및 $\mathrm{Ca} \times 25-(\mathrm{OH}) \mathrm{D}_{3}$ 의 interaction에서 유의한 변화가 없는 것으로 나타났다. 혈청 내 GPT 수준은 $\mathrm{Ca}$ 급여 수준의 변화에 따라 유의한 차이 가 인정되었으나 $(\mathrm{P}<0.01), 25-(\mathrm{OH}) \mathrm{D}_{3}$ 의 첨가 수준의 변화 에 따른 차이는 발견되지 않았다. 혈청 내 $\mathrm{P}$ 농도는 $25-(\mathrm{OH}) \mathrm{D}_{3}$ 의 첨가 수준의 변화에 따른 변화는 관찰되지 않았으며, $\mathrm{Ca}$ 급여 수준의 변화에 따라 유의한 차이가 인 정되었다 $(\mathrm{P}<0.01)$. 대조적으로 $\mathrm{Ca}$ 농도는 $\mathrm{Ca}$ 급여 수준의 변화에 따른 차이는 인정되지 않았고, $25-(\mathrm{OH}) \mathrm{D}_{3}$ 의 첨가 수준의 변화에 따른 유의한 차이가 관찰되었다 $(\mathrm{P}<0.05)$.

본 실험에서는 혈청 albumin 및 $\mathrm{BUN}$ 농도 분석과 조직 손상의 지표가 되는 효소 활성에 대한 분석을 통해 $\mathrm{Ca}$ 의 고 수준 급여 및 $25-(\mathrm{OH}) \mathrm{D}_{3}$ 의 첨가 급여에 의한 생리적
변화를 조사하였으나, 처리간에 큰 차이는 발견하지 못하 였다. 생산성 및 생리적 변화에 대한 결과로부터 $\mathrm{Ca}$ 의 고 수준 급여 및 25- $(\mathrm{OH}) \mathrm{D}_{3}$ 의 첨가 급여에 의한 부정적인 영 향은 없는 것으로 생각된다. $\mathrm{Ca}$ 급여 수준이 증가함에 따 라 혈청 내 GPT 수준이 유의하게 감소하였으나 $(\mathrm{P}<0.01)$, 정상범위 내에 포함되는 점 $(\mathrm{Lumeij,} \mathrm{1997)을} \mathrm{고려한다면}$ 큰 의미는 없을 것으로 사료된다. $\mathrm{Ca}$ 의 급여 수준과 혈중 $\mathrm{Ca}$ 및 $\mathrm{P}$ 농도의 연관성에 대해서는 연구에 따라 상당한 차이가 관찰된다. Abdallah 등(1993)은 $\mathrm{Ca} \mathrm{1.7 \%}$ 급여구에 서의 혈중 $\mathrm{Ca}$ 농도는 $\mathrm{Ca} 3.9 \%$ 이상 급여구와 비교하여 유의한 감소를 나타내었다고 하였다. 대조적으로 Keshavarz (1986)은 $\mathrm{Ca}$ 수준이 $3.5,4.5$ 및 5.5\%인 실험사료를 급여했 던 연구에서 혈장 내 $\mathrm{Ca}$ 농도가 처리간에 차이가 없었다 는 본 실험과 일치하는 결과를 보고하였다.

Frost와 Roland (1991)는 사료 내 $\mathrm{Ca}$ 및 $\mathrm{P}$ 수준을 다양 하게 조절한 실험사료를 급여했을 때 혈장 내 총 $\mathrm{Ca}, \mathrm{P}$ $\mathrm{Na}^{+}$및 $\mathrm{Cl}^{-}$농도에서 유의한 차이를 발견하지 못하였다. Keshavarz (1986) 역시 $\mathrm{Ca}$ 수준이 각기 다른 사료를 급여 한 결과, 혈장 내 $\mathrm{P}$ 농도에서 큰 차이가 없었다고 본 연 구와는 상이한 결과를 보고하였다. 그러나 Roland와 Gordon (1997)은 사료의 $\mathrm{Ca}$ 수준이 증가하면 혈장 $\mathrm{Ca}$ 농도

Table 7. Effects of dietary calcium and 25-hydroxycholecalciferol on blood profiles of aged egg-type breeder layers ${ }^{1,2)}$

\begin{tabular}{|c|c|c|c|c|c|c|}
\hline Treatments $^{3)}$ & Albumin $(\mathrm{g} / d l)$ & GOT (U/L) & GPT (U/L) & $\begin{array}{l}\mathrm{BUN} \\
(\mathrm{mg} / d l)\end{array}$ & $\underset{(\mathrm{mg} / d l)}{\mathrm{Ca}}$ & $\begin{array}{c}\mathrm{P} \\
(\mathrm{mg} / d l)\end{array}$ \\
\hline $\mathrm{T} 1$ & $2.11 \pm 0.04$ & $169.86 \pm 4.56$ & $16.92 \pm 2.33$ & $2.40 \pm 0.14$ & $27.07 \pm 1.19$ & $7.31 \pm 0.39$ \\
\hline $\mathrm{T} 2$ & $2.16 \pm 0.06$ & $185.50 \pm 20.16$ & $24.85 \pm 5.88$ & $2.43 \pm 0.41$ & $21.67 \pm 3.45$ & $7.82 \pm 0.95$ \\
\hline $\mathrm{T} 3$ & $2.15 \pm 0.05$ & $185.29 \pm 15.66$ & $16.64 \pm 1.97$ & $1.60 \pm 0.15$ & $20.66 \pm 1.30$ & $7.41 \pm 0.75$ \\
\hline $\mathrm{T} 4$ & $2.16 \pm 0.05$ & $194.64 \pm 17.49$ & $14.21 \pm 1.70$ & $2.15 \pm 0.55$ & $24.31 \pm 1.91$ & $6.00 \pm 0.55$ \\
\hline $\mathrm{T} 5$ & $2.07 \pm 0.03$ & $175.07 \pm 7.40$ & $13.42 \pm 0.70$ & $1.75 \pm 0.16$ & $20.80 \pm 1.91$ & $5.80 \pm 0.40$ \\
\hline T6 & $2.11 \pm 0.03$ & $191.79 \pm 16.04$ & $15.64 \pm 0.70$ & $1.90 \pm 0.25$ & $21.69 \pm 1.04$ & $6.11 \pm 0.34$ \\
\hline $\mathrm{T} 7$ & $2.14 \pm 0.04$ & $180.07 \pm 8.81$ & $10.35 \pm 0.93$ & $1.81 \pm 0.16$ & $23.56 \pm 1.22$ & $6.04 \pm 0.31$ \\
\hline $\mathrm{T} 8$ & $2.06 \pm 0.08$ & $178.14 \pm 7.84$ & $12.50 \pm 1.20$ & $1.86 \pm 0.18$ & $22.30 \pm 1.24$ & $4.04 \pm 0.89$ \\
\hline T9 & $2.26 \pm 0.08$ & $210.00 \pm 9.58$ & $14.57 \pm 0.77$ & $2.07 \pm 0.22$ & $24.77 \pm 1.31$ & $3.98 \pm 0.88$ \\
\hline $\mathrm{Ca}$ & NS & NS & $\mathrm{P}<0.01$ & NS & NS & $\mathrm{P}<0.01$ \\
\hline $25-(\mathrm{OH}) \mathrm{D}_{3}$ & NS & NS & NS & NS & $\mathrm{P}<0.05$ & NS \\
\hline $\mathrm{Ca} \times 25-(\mathrm{OH}) \mathrm{D}_{3}$ & NS & NS & $\mathrm{P}<0.05$ & NS & NS & $\mathrm{P}<0.01$ \\
\hline
\end{tabular}

1) 25-(OH)D 3 , 25-hydroxycholecalciferol; GOT, glutamic-oxaloacetic transaminase; GPT, glutamic-pyruvic transaminase; BUN, blood urea nitrogen.

2) $\mathrm{Mean} \pm \mathrm{SE}$

${ }^{3)} \mathrm{T} 1, \mathrm{Ca} 3.3 \%-25(\mathrm{OH}) \mathrm{D}_{3} 0 \mu \mathrm{g} ; \mathrm{T} 2, \mathrm{Ca} 3.3 \%-25(\mathrm{OH}) \mathrm{D}_{3} \quad 75 \mu \mathrm{g} ; \mathrm{T} 3, \mathrm{Ca} 3.3 \%-25(\mathrm{OH}) \mathrm{D}_{3} \quad 150 \mu \mathrm{g} ; \mathrm{T} 4, \mathrm{Ca} \quad 3.9 \%-25(\mathrm{OH}) \mathrm{D}_{3} \quad 0 \mu \mathrm{g} ; \mathrm{T} 5, \mathrm{Ca}$ $3.9 \%-25(\mathrm{OH}) \mathrm{D}_{3} 75 \mu \mathrm{g} ; \mathrm{T} 6, \mathrm{Ca} 3.9 \%-25(\mathrm{OH}) \mathrm{D}_{3} 150 \mu \mathrm{g} ; \mathrm{T} 7, \mathrm{Ca} \quad 4.5 \%-25(\mathrm{OH}) \mathrm{D}_{3} \quad 0 \mu \mathrm{g} ; \mathrm{T} 8, \mathrm{Ca} \quad 4.5 \%-25(\mathrm{OH}) \mathrm{D}_{3} \quad 75 \mu \mathrm{g} ; \mathrm{T} 9, \mathrm{Ca} \quad 4.5 \%-$ $25(\mathrm{OH}) \mathrm{D}_{3} 150 \mu \mathrm{g}$. 
가 올라가고 $\mathrm{P}$ 의 농도가 떨어짐에 따라 난각 두께가 증가 한다고 하였다. 사료 내 $\mathrm{Ca}$ 수준이 달라질 때 나타나는 혈중 $\mathrm{Ca}$ 및 $\mathrm{P}$ 농도의 변화는 연구에 따라 그 결과가 상이 하며, 난각질과의 연관성 역시 명확하지 않다. 한편 본 실 험에서는 $\mathrm{Ca}$ 급여 수준이 증가함에 따라 난각질이 유의하 게 개선된 반면 혈중 $\mathrm{Ca}$ 농도에는 변화가 없었는데, 이는 난각질이 우수한 개체와 그렇지 않은 개체를 비교한 연구 에서 혈중 $\mathrm{Ca}$ 농도가 난각질을 평가하기 위한 좋은 지표 가 아니라고 보고한 Kang 등(1996)의 연구를 지지하는 결 과가 시사되었다.

\section{IV. 요 약}

본 실험에서는 사료 내 $\mathrm{Ca}$ 공급 수준의 증가 및 25$(\mathrm{OH}) \mathrm{D}_{3}$ 의 첨가 급여가 산란종계에서 후기 난각질 강화 및 종란 생산성에 미치는 영향을 검토하기 위한 목적으로 수 행하였다. 60주령 Hy-Line Brown 산란종계 암탉 540수와 수탉 54수를 공시하여 사료 내 $\mathrm{Ca}$ 을 $3.3 \%, 3.9 \%$ 및 $4.5 \%$ 로 하고, 25- $(\mathrm{OH}) \mathrm{D}_{3}$ 를 각각 0,75 및 $150 \mu \mathrm{g} / \mathrm{kg}$ 수준으로 첨가한 총 9 개 실험사료를 10 주간 급여하였다. 주별로 사 료섭취량을 조사하였고, 산란율과 난중은 매일 조사하였 다. 종란율과 부화율 조사를 위해 생산된 종란을 주별로 처리하였다. 실험사료 급여 후 주별로 생산된 계란을 반 복구별로 10 개씩 수집하여 난각질 측정에 이용하였다. 실 험 종료 시 반복구별로 평균체중이 비슷한 개체를 선발하 여 채혈 후 희생시킨 다음 경골을 적출하였다. 채취한 경 골은 화학적 조성의 분석을 위한 시료로 이용하였고, 얻 어진 혈액에서도 성분 분석을 실시하였다. 산란율은 $\mathrm{Ca}$ $3.9 \%$ 첨가구가 $\mathrm{Ca} 3.3 \%$ 와 $\mathrm{Ca} 4.5 \%$ 첨가구에 비해 유의한 증가가 나타났으며 $(\mathrm{P}<0.01), \quad 25-(\mathrm{OH}) \mathrm{D}_{3}$ 의 무첨가구에서 $25-(\mathrm{OH}) \mathrm{D}_{3}$ 첨가구에 비해 유의하게 $(\mathrm{P}<0.01)$ 높게 나타났 다. 난각강도는 $\mathrm{Ca} 4.5 \%$ 첨가구가 $\mathrm{Ca} 3.9 \%$ 와 $\mathrm{Ca} 3.3 \%$ 첨 가구에 비해 유의하게 개선되었으며 $(\mathrm{P}<0.01), \quad 25-(\mathrm{OH}) \mathrm{D}_{3}$ $150 \mu \mathrm{g} / \mathrm{kg}$ 첨가구에서 $25-(\mathrm{OH}) \mathrm{D}_{3} \quad 70 \mu \mathrm{g} / \mathrm{kg}$ 첨가구와 25$(\mathrm{OH}) \mathrm{D}_{3}$ 무첨가구에 비해 유의하게 개선되었다 $(\mathrm{P}<0.01)$. 수 정율은 $\mathrm{Ca}$ 급여수준 변화 및 $25-(\mathrm{OH}) \mathrm{D}_{3}$ 의 첨가 급여에 따 라 처리구간에 큰 차이는 없는 것으로 나타났으나, 입란 대 부화율은 $25-(\mathrm{OH}) \mathrm{D}_{3} \quad 150 \mu \mathrm{g} / \mathrm{kg}$ 첨가구에서 $25-(\mathrm{OH}) \mathrm{D}_{3}$ 무첨가구에 비해 유의하게 $(\mathrm{P}<0.05)$ 높게 인정되었다. 경골 내 $\mathrm{Ca}$ 함량은 $\mathrm{Ca} 4.5 \%$ 급여구에서 $\mathrm{Ca} 3.3 \%$ 급여구 및 $\mathrm{Ca}$ $3.9 \%$ 급여구에 비해 유의한 차이가 나타났으나 $(\mathrm{P}<0.05)$, $25-(\mathrm{OH}) \mathrm{D}_{3}$ 의 첨가 효과는 인정되지 않았다. 상기의 결과 로부터 산란종계의 후기 난각질 개선을 위해서는 사료 내 의 $\mathrm{Ca}$ 수준을 비교적 높게 설정하는 것이 유리하며, 25$(\mathrm{OH}) \mathrm{D}_{3}$ 의 첨가에 의해서도 난각질이 개선될 수 있는 것으 로 나타났다. 또한 $25-(\mathrm{OH}) \mathrm{D}_{3}$ 를 $150 \mu \mathrm{g} / \mathrm{kg}$ 첨가에 의해 입
란대 부화율이 유의하게 개선되는 결과가 시사되었다. 그 러나 25- $(\mathrm{OH}) \mathrm{D}_{3}$ 를 $150 \mu \mathrm{g} / \mathrm{kg}$ 수준으로 첨가했을 때 관찰된 산란율의 저하에 대해서는 그 원인을 밝히기 위한 추가적 인 연구가 필요하겠다.

$$
\mathrm{V} \text {. 사 사 }
$$

본 연구는 농림수산식품부 농림기술개발사업과 재단법 인 양영재단의 지원에 의하여 수행되었으며, 이에 감사드 립니다.

\section{VI. 인 용 문 헌}

1. Abdallah, A. G., Harms, R. H. and El-Husseiny, O. 1993. Performance of hens laying eggs with heavy or light shell weight when fed diets with different calcium and phosphorus levels. Poultry Sci. 72:1881-1891.

2. Abdulrahim, S. M., Patel, M. B. and McGinnis, J. 1979. Effects of vitamin $\mathrm{D}_{3}$ and $\mathrm{D}_{3}$ metabolites on production parameters and hatchability of eggs. Poultry Sci. 58:858-863.

3. Al-Batshan, H. A., Scheideler, S. E., Black, B. L., Garlich, J. D. and Anderson, K. E. 1994. Duodenal calcium uptake, femur ash, and eggshell quality decline with age and increase following molt. Poultry Sci. 73:1590-1596.

4. Ameenuddin, S. 1984. Nutritional evaluation of vitamin D metabolites and leaf protein concentrates on the productive and reproductive performance of poultry. Ph.D. dissertation. University of Wisconsin, Madison, WI.

5. Angel, R., Applegate, T. J., Christmas, M. and Dhandu, A. S. 2001. Phosphorus sparing effect of phytase, 25-hydroxycholecalciferol and citric acid when fed to broiler chicks. Poultry Sci. 80(Suppl.) 134.

6. Applegate, T. J., Angel, R., Classen, H. L., Newkirk, R. W. and Maenz, D. D. 2000. Effect of dietary calcium concentration and 25-hydroxycholecalciferol on phytate hydrolysis and intestinal phytase activity in broiler. Poultry Sci. 79(Suppl.) 21.

7. Bar, A., Razaphkovsky, V. and Vax, E. 2002. Re-evaluation of calcium and phosphorus requirements in aged laying hens. Br. Poultry Sci. 43:261-269.

8. Chang, T. K. and Coon, C. N. 1990. Sensitivity of various bone parameters of laying hens to different daily calcium intake. Poultry Sci. 69:2209-2213.

9. Charles, O. W., Duke, S. and Reddy, B. 1978. Further studies on the response of laying hens to 25-hydroxy cholecalciferol. Poultry Sci. 57:1098-1099. 
10. Charles, O. W. and Ernst, R. A. 1973. Effect of age, calcium levels, and vitamin D metabolites on egg shell quality of SCWL. Poultry Sci. 52:1908.

11. Clunies, M., Park, D. and Leeson, S. 1992. Calcium and phosphorus metabolism and eggshell formation of hens fed different amounts of calcium. Poultry Sci. 71:482-489.

12. Damron, B. L. and Harms, R. H. 1980. Interaction of dietary slat, calcium and phosphorus level for laying hens. Poultry Sci. 59:82-85

13. Duncan, D. B. 1955. Multiple range and multiple $F$ tests Biometr. 11:1-42.

14. Frost, T. J. and Roland, D. A. Sr. 1991. The influence of calcium and phosphorus levels on tibia strength and eggshell quality of pullets during peak production. Poultry Sci. 70: 963-969.

15. Garlich, J., Brake, J., Parkhurst, C. R., Thaxton, J. P. and Morgan, G. W. 1984. Physiological profile of caged layers during one production year, molt and postmolt: egg production, egg shell quality, liver, femur, blood parameters. Poultry Sci. 63:339-343.

16. Gilbert, A. B., Peddie, J., Mitchell, G. G. and Teague, P. W. 1981. The egg-laying response of the domestic hen to variation in dietary calcium. Br. Poultry Sci. 22:537-548.

17. Harms, R. H. and Waldroup, P. W. 1961. The influence of dietary calcium level and supplementary ascorbic acid and/or dienestrol diacetate upon performance of egg production type hen. Poultry Sci. 40:1345-1348.

18. Hamilton R. M. G. 1980. The effects of dietary phosphorus, vitamin $\mathrm{D}_{3}$ and 25-hyroxyvitamin $\mathrm{D}_{3}$ levels on feed intake, productive performance, and egg and shell quality in two strains of force-molted White Leghorns. Poultry Sci. 59:598-604

19. Hartel, H. 1989. Evaluation of the dietary interaction of calcium and phosphorus in the high producing laying hen. $\mathrm{Br}$. Poultry Sci. 31: 473-494.

20. Hurwitz, S. and Griminger, P. 1962. Estimation of calcium and phosphorus requirements in laying hens by balance techniques. J. Sci. Food. Agri. 13:185-192.

21. Hurwitz, S. and Bornstein, S. 1966. The effect of high dietary calcium on the performance of laying hens fed rations of varying energy levels. Poultry Sci. 45:805-809.

22. Hy-Line VARIETY Brown 2000. Parent Stock Management Guide.

23. Jackson, M. E., Hellwig, H. M. and Waldroup, P. W. 1987. Shell quality : Potential for improvement by dietary means and relationship with egg size. Poultry Sci. 66:1702-1713.
24. Kang, C. W., Nam, K. T., Olson, O. E. and Carlson, C. W. 1996. Relationships between eggshell quality and biochemical parameters of calcium metabolism. Asian-Aust. J. Anim. Aci. 9:715-722.

25. Keshavarz, K. 1986. The effect of variation of calcium intake on production performance and shell quality. Poultry Sci. 65:2120-2125.

26. Keshavarz, K. 2000. Shell quality and bone mineralization : An overview of research at cornell university. Cornell Poultry Pointers vol. 50:7.

27. Keshavarz, K. 2003. A comparison between cholecalciferol and 25-OH-cholecalciferol on performance and eggshell quality of hens fed different levels of calcium and phosphorus. Poultry Sci. 82:1415-1422.

28. Keshavarz, K. and Nakajima, S. 1991. Re-evaluation of calcium and phosphorus requirement of laying hens for optimum performance and egg shell quality. Poultry Sci. 60(Suppl.) 63.

29. Lumeij, J. T. 1997. Avian Clinical Biochemistry. In: Clinical Biochemistry of Domestic Animals (ed. J. J. Kanebo, J. W. Harvey, and M. L. Bruss, 5th) Academic Press. pp. 857-883.

30. Manley, J. M., Voitle, R. A. and Harms, R. H. 1978. The influence on hatchability of turkey eggs from the addition of 25-hydroxycholecalciferol to the diet. poultry Sci. 57:290-292.

31. Marret, L. E., Frank, F. R. and Zimbleman, R. G. 1975. 25-hydroxycholecalciferol as a dietary replacement of vitamin $\mathrm{D}_{3}$ to improve egg shell calcification. Poultry Sci. 54:1788. (Abstr.).

32. McLoughlin, C. P. and Soares, J. H. Jr. 1976. A study of the effects of 25-hydroxycholecalciferol and calcium source on egg shell quality. Poultry Sci. 55:1400-1410.

33. McNaughton, J. L., Day, E. J. and Dilworth, B. C. 1977. The chick's requirement for 25-hydroxycholecalciferol and cholecalciferol. Poultry Sci. 56:511-516.

34. Mehring, A. L. and Titus, H. W. 1964. The effect of low levels of calcium in the diet of laying chickens. Poultry Sci. 43:1405-1414.

35. National Research Council 1984. Nutrient requirements of poultry, 8th ed. Natl. Acad. Sci., Washington, DC.

36. National Research Council 1994. Nutrient requirements of poultry, 9th ed. Natl. Acad. Sci., Washington, DC.

37. Ousterhout, L. E. 1980. Effects of calcium and phosphorus levels on egg weight and egg shell quality in laying hens. Poultry Sci. 59:1480-1484.

38. Polin, D. and Ringer, R. K. 1977. 25-hydroxy- $D_{3}$, vitamin $D_{3}$ and graded levels of phosphorous: effect on egg production 
and shell quality. Feedstuffs 49:40-42.

39. Roland, D. A. Sr. and Gordon, R. 1997. Phosphorus, calcium optimization requires new approach. Feedstuffs. April 7, 1997 p14.

40. SAS. 2002. SAS User's Guide. Statistics, Version 8.e, SAS Institute. Inc., Cary, NC.

41. Scott, M. L., Hull, S. J. and Mullenhoff, P. A. 1971. The calcium requirements of laying hens and effects of dietary oyster shell upon egg shell quality. Poultry Sci. 50:10551063.

42. Seldin, E. D. 1965. Arheologic model for cornical bone. Acta. Orthop. Scand. 36(Suppl. 83):1-77.

43. Soares, J. H. Jr., McLoughlin, C. M., Swerdel, M. R. and Bossard, E. 1976. Effects of hydroxy vitamin D metabolites on the mineralization of egg shells and bones. Pages 85-92 in: Proceedings of the Maryland Nutrition Conference. Washington, DC.
44. Soares, J. H. Jr., Kerr, J. M. and Gray, R. W. 1995. 25-hydroxycholecalciferol in poultry nutrition. Poultry Sci. 74:1919-1934.

45. Soares, J. H. Jr., Swerdel, M. R. and Bossard, E. H. 1978. Phosphorus availability 1 . The effect of chick age and vitamin D metabolites on the availability of phosphorus in defluorinated phosphate. Poultry Sci. 57:1305-1312.

46. Walter, E. D. and Aitkin, J. R. 1962. Phosphorus requirement of laying hens confined to cages. Poultry Sci. 41:386-392.

47. 박경우. 2003. 인결핍 사료에 있어서 $25-(\mathrm{OH}) \mathrm{D}_{3}$ 첨가가 육계 의 생산성 및 경골의 발달에 미치는 영향. 건국대학교 대학 원 석사학위 청구논문.

48. 한인규, 이규호, 이상진, 강태홍, 권관. 1981. 산란계에 대한 칼슘 공급제의 사료가치 비교시험. 2. 칼슘 공급수준이 산란 율, 난각질 및 사료효율에 미치는 영향. 한축지 23:199-205.

(접수일자 : 2009. 2. 20. / 수정일자 : 2009. 8. 14. /

채택일자 : 2009. 8. 18.) 